\title{
Philosophy as transformative practice: a proposal for a new concept of philosophy that better suits philosophy education
}

\author{
Philipp THOMAS*
}

\begin{abstract}
The source of the following considerations is the observation that academic philosophy at universities does not fit well with philosophy education processes, e.g., those at school. Both sides seem to be separate from each other. I assume that the two areas rely on two very different concepts of philosophy. To work out a concept of philosophy more appropriate to the educational context, I methodically apply the practical turn to our philosophising in very different contexts. Moreover, I elaborate that it is precisely the modern scientific paradigm that underlies philosophy as scientific practice and that the former represents a problematic constriction of philosophising in educational contexts. For where the ideal is objective scientific knowledge - from which everything subjective has been removed - there can be no deeper transformation of the subject through philosophy. My thesis is that philosophy is better suited to the educational context as transformative and not as scientific practice. As a consequence, the question arises as to whether the study of philosophy on teacher training courses needs a new impulse in the direction of philosophy as transformative practice.
\end{abstract}

\section{KEY WORDS}

philosophy of education; theories of education; practical turn and philosophy; modern scientific paradigm and philosophy; subject-specific didactics philosophy; philosophy education; philosophy at school

* $\mathrm{PhD}$, professor of philosophy and ethics, University of Education Weingarten, Germany. E-mail: thomas01@ph-weingarten.de. 


\section{THE THESIS}

We can call the academic concept of philosophy: philosophy as scientific practice. This concept does not fit well the educational goals of philosophy lessons in schools. Nor does it fit well what people expect from philosophy, whose interest in philosophy stems from their own questions about life because the academic concept of philosophy goes back to the modern scientific paradigm (Böhme, 1994: 19). In these frames, the truth of a particular philosophical thought should be possibly objective. All the subjective rest is eliminated. In contrast, philosophy within the context of philosophy education should enable the thinking subject to move forward and change itself by means of philosophising (Peters \& Peters, 2019; Nida-Rümelin, Spiegel, \& Tiedemann, 2017). There is more to be learned in education than just logical thinking. For all those goals of philosophy education that exceed logical thinking, we need a new concept of philosophy. Thus, I propose to understand philosophy as a transformative practice in the context of education.

\section{THE FIRST PREREQUISITE FOR THE NEW CONCEPT OF PHILOSOPHY: WE MAY APPLY THE PRACTICAL TURN TO PHILOSOPHY}

The practical turn is a term from the social sciences (e.g. Schatzki, 2001; Stern, 2003). It describes a change of course in scientific interests. The focus no longer is on the question of what $\mathrm{x}$ is or what the truth of $\mathrm{x}$ is. Instead, we now observe the many practices in the area of human life and actions. We ask how the meaning of $x$ arises in the context of these practices. We are not used to applying the practical turn to philosophy because philosophy asks about eternal truths. But on the other hand, important traditions of the twentieth century proceed analogously to the practical turn. Martin Heidegger analysed in his early main work Being and time how the meaning of the term "being" depends on practices. The same thing has a different being when we use it than when we observe it scientifically (Heidegger, 1927/1996: §§ 14-19 \& 69b). Approximately at the same time, Karl Mannheim shows how scientific results depend on the respective historical and social context (Mannheim, 1929/1936). Michel Foucault (Foucault, 1982) does not ask: What is the subject? Instead, he asks: Which practices - like self-discipline - form the subject, and to what end? And Judith Butler (Butler, 2015) does not ask: What are, ontologically speaking, men and women? Instead, she asks: Which practices, like speech and behaviour, form our understanding of men and women?

Because philosophy is close to this kind of thinking, we can also apply the practical turn to philosophy and observe the practices of philosophising. Then 
we do not ask: What is philosophy? Instead, we ask: How does a certain concept of philosophy shape the practices of our philosophising, e.g., at university or school. Or vice versa: To which concept of philosophy do certain practices of philosophising lead us? For instance, does the practice of philosophising in the educational context need a different concept of philosophy? I will pursue these questions below.

\section{THE SECOND PREREQUISITE FOR THE NEW CONCEPT OF PHILOSOPHY: WE SHOULD REVISE THE CONSTRICTION OF PHILOSOPHY CREATED BY THE MODERN SCIENTIFIC PARADIGM}

Scientific philosophy at universities perceives itself as the one institution that upholds the tradition of philosophy and classical philosophical problems. It seems the only legitimate heir to the tradition. All beside philosophy would then be described as popular, non-scientific, or simplified philosophy, which does not attain the level of scientific philosophy. Thus, such a self-understanding of academic philosophy also shapes the model of philosophy education, for instance, in school. Students who want to teach philosophy at school must first learn philosophy as scientific practice, because there seems to be no other philosophy available. Moreover, and often later, they have to acquire the ability to explain, convey, and teach philosophy, following the usual model. Examination regulations only provide for additional courses in teaching philosophy whose focus, however, primarily lies in methodology. According to this model of teaching philosophy, in subject specific didactics we merely ask: How best to explain certain philosophers? How should we prepare philosophical topics for lessons? Which methods fit to which topics and to which class levels? Which media are suitable: texts, pictures, films, product-oriented activities?

I propose a different approach to develop new concept of philosophy, one that better fits the context of education. Philosophy as scientific practice is not the only legitimate heir to the tradition of philosophy and classical philosophical questions, but one heir among several. Because this philosophical practice is constricted by the modern scientific paradigm it cannot assume its whole legacy. Where the ideal consists in objective scientific knowledge gained within a scientific community, everything subjective is inappropriate and must be eliminated (Böhme, 1994: 215-217). This modern notion of scientific philosophy dates back to Francis Bacon's Novum Organum. In his theory of idols, especially Idols of the Cave, F. Bacon indicates that every researcher has his own cave that stems from his individual experience, nature, or education (Nov. Org., Aph. 42). Philosophy as scientific practice does not depend on whether the philosophising subject had certain individual experiences that 
influenced his thought. Nor does it depend on whether the philosophising subject defines itself in its humanity through certain philosophical or ethical judgements that it makes, thus consciously deciding on its identity. Nor does philosophy as scientific practice depends on whether the philosophising subject becomes a better human being, e.g. through ethical reflection. We may easily imagine a good university philosopher who does not need to show any personal development (Böhme, 1994: 19). Moreover, academic philosophy usually views one's attempts to express individual experience through philosophy with indifference. All this is not important for philosophy as scientific practice; although, it is of great importance for the field of philosophy education, as it belongs to its valuable potential. Therefore, allow me to formulate affairs in a somewhat simplified manner: philosophy as scientific practice does not care what the subject of philosophy education is. The former only understands that philosophy education means to know a lot about the philosophical tradition and to learn logically thinking.

But this is exactly what constricts the concept of philosophy education. Thus, in the interest of a more comprehensive philosophy education, we must first indicate that philosophy constricted itself by following the modern scientific paradigm. Ancient philosophy still knew a philosophising that firstly enriched and changed the philosophising subject and created its identity as a human being (e.g., Arist. Eth. Nic. A 3 1095b-1096a10; Hadot, 1995). Philosophy can still follow this tradition today. Therefore, it is important which subject thinks a philosophical thought. Moreover, one cannot philosophise without transforming the relation to oneself and the world.

If we assume that philosophy as scientific practice has a constricted concept of philosophy, we may demand a completely different concept of philosophy for the field of philosophy education, a concept that in its heart positions change and transformation. This shift influences the model in which we train students who want to become philosophy teachers in schools. In this new model - which has been called philosophy as transformative practice ${ }^{1}-$ sci- $^{-}$ entific philosophy does not first define what philosophy is. Moreover, it does not suffice to train teacher students in subsequent and purely methodology-oriented courses in teaching philosophy. Instead, my approach views philosophy differently from the outset: not on the basis of the modern ideal of science but in relation to the ancient and modern traditions of personality development through philosophical reflection. According to this model of philosophy education - including the training of philosophy teachers - philosophy as transformative practice is a further heir to the philosophical tradition, which sets it on an equal footing with philosophy that follows the modern paradigm of science. Philosophy as transformative practice represents a very special way

\footnotetext{
${ }^{1}$ An initial version of these considerations can be found in Thomas, 2019.
} 
of addressing the great questions of philosophy and decrees different practices than scientific philosophy.

Having said this, we have to avoid a possible misunderstanding. What students do in academic philosophy as living practice is much more than mere academic practice. Reflecting on our culture and considering our habits of thinking is typical for the Humanities and will in this or that way change students' lives. On the other hand, philosophy as transformative practice, e.g., in educational processes, is much more than simply "giving advice" or some kind of personal development. Instead, we have to work hard, we have to read and write, it needs reflection and discussion in order to transform our lives by philosophising. However, as a heuristic method it seems fruitful to draw a distinction between the two practices.

\section{THE DISTINCTION BETWEEN PHILOSOPHY AS SCIENTIFIC PRACTICE AND PHILOSOPHY AS TRANSFORMATIVE PRACTICE IN THE AREAS OF (3.1.) PHILOSOPHICAL RESEARCH, (3.2.) THE PHILOSOPHISING SUBJECT, AND (3.3.) PHILOSOPHY EDUCATION}

\subsection{Philosophical Research}

Scientific and transformative philosophy differ in what many consider a relevant research question. We know the scientific questions of philosophy. But what about philosophical research in philosophy as transformative practice? I want to support the following thesis: Every important philosophy that makes the world visible in a new way - be it Plato's or Immanuel Kant's, Aristotle's or Ludwig Wittgenstein's, Georg Wilhelm Friedrich Hegel's, or Michel Foucault's - implicitly answers what we should do to be considered philosophically educated (Dammer, 2015; Dammer \& Kirschner, 2017; Benner \& Brüggen, 2004). In a way, these answers are the transformative potentials of all great philosophies. These transformative potentials can induce the growth and education of philosophising subjects.

Research in the sense of philosophy as transformative practice must develop these implicit potentials and make them explicit. I shall name a few examples below, firstly always research questions of scientific philosophy, then research questions of transformative philosophy: How can Platonic ideas be regarded as metaphysical causes? What transformative potential can Plato's term of idea offer, as the concept of the world fundamentally changes as a result of it? Does Kant succeed in thinking the "thing-in-itself" without any objective representation? What transformative potential can radical insight into the boundaries of knowledge offer philosophising 
subjects? What influence did Friedrich Nietzsche's term of self-overcoming (die Selbstüberwindung) have on Sigmund Freud's term of sublimation (die Sublimierung)? What transformative potential is contained in Nietzsche's term of self-overcoming and Freud's term of sublimation? These examples clarify that philosophy as scientific practice seeks a rational reconstruction of philosophical problems and then their further development, as discussed by the academic community on the research front. Whereas philosophy as transformative practice seeks the transformative potential of philosophies and then the education of philosophising subjects, not to mention the ability to reflect on questions about one's own identity.

\subsection{The Philosophising Subject}

Imagine we are listening to a lecture at a philosophical institute colloquium. The lecture mostly addresses us as the subjects of our thinking. If we expect answers to questions about our life, we will be disappointed. This is how philosophy as scientific practice functions. Lectures and journal articles promote thinking: someone formulates theses and justifies them as well as possible. Other researchers then criticise these theses. Finally, the theses and the justifications are further developed and improved. The subjects here are only addressed as thinking. Something different happens in philosophy as transformative practice. Educational processes also always turn to the subject as a thinking one. But we want more. We also address the subject as a subject of life practices. The learning and philosophising subjects should reflect on their conception of themselves, their life, or actions in various areas, criticise them, and possibly realign them (e.g., Tiedemann, 2017: 71; Stelzer, 2017). We do not primarily seek objective truths which are purified of all traces of the subjective. Rather, it is always about a subject that is situated, that is precisely this individual person who lives in this place at this time and who encounters precisely these fellow human beings, decisions, or challenges. This situated subject is the subject of concrete life practices and the subject of an individual life that it somehow has to live. It is the subject who - in decisions and their justifications - also decides on their own identity as a human being. And it is the subject that philosophises against the background of their own individual experiences and seeks to articulate these experiences. Philosophy should help them with all of this. For philosophy as scientific practice, the situated, concrete, and individual subject is ultimately dispensable. Such a subject is only interesting as a thinking entity. For philosophy as transformative practice, the concrete subject is central and indispensable, because the goal being transformative processes that result from philosophical reflection. 
It was Pierre Hadot who pointed out that philosophy had initially been a way of life. For philosophers the ultimate goal of arguing and reasoning was to make some progress on "their path toward their own perfection" (Hadot, 1995: 162). Philosophers debated and discussed because this was a means of "self-knowledge and self-cultivation", "self-examination and self-care" (Shusterman, 2013: 51, 54). Above all, it was Socrates who philosophised in a transformative manner. In the Symposium, as Hadot pointed out, Socrates as the role model of a philosopher is compared to Eros who is in search of love since he has not yet reached it. Likewise, the philosopher is in search for wisdom since he has not yet reached it. Socrates the philosopher "is Eros, which means that he is desire - not a passive and nostalgic desire, but desire which is impetuous, and worthy of Eros, the 'dangerous hunter"' (Hadot, 2002: 45). Socrates leads his interlocutors in their desires for beauty, for love, and for wisdom. This guidance, however, does not mean giving advice but does mean giving the opportunity of growing and of transformation. For the seekers both can change by discussing with Socrates in the Symposium, their desire itself and the objects which they desire. Their longing for physical beauty turns out to be, on a deeper level, their longing for final truth. Philosophy, by inference and as Hadot put it, is first of all a way of life which combines reasoning and personal transformation (Hadot, 2002: 39-51).

\subsection{Philosophy Education}

Philosophy as scientific practice primarily trains students to enable them to participate within the scientific community. The principle of such education is science propaedeutic. The following example shows it best. Let us assume that we, as schoolteachers of philosophy, knew that all our students would like to study philosophy after graduating from high school and that all of them would become philosophy professors afterwards. How should philosophy education look in our class? Philosophy as scientific practice would teach science skills to students in a purely propaedeutic manner, e.g., how to logically reconstruct a problem, how to argue, and how to write scientific articles (e.g., Feinberg, 2002). On the other hand, philosophy as transformative practice would argue what follows: Even in a school class, in which everyone is later to become philosophy professors, they will be more than just that, as they will all be fathers or mothers, spouses, citizens, patients. They may also be representatives of minorities, political activists, organ donors, aware or unaware patients. Philosophy education addresses concretely situated subjects who have gathered irreducible individual experiences and - in their philosophising decide about themselves and the world. These decisions lead to actions. We all should also be able to think logically. However, we may say that rationality 
serves good, that is, a good society and good life. Philosophy as transformative practice depends here on becoming not only a good philosopher but a good human being through philosophy education.

\section{IS THE DISTINCTION TOO SIMPLE? TWO POSSIBLE OBJECTIONS}

Does philosophy as scientific practice not equally have a transformative effect? Yes, the result of this philosophy education will be an attitude that is scientific, rational, and objective. This is very valuable. We miss this attitude when we discuss with people who are not scientifically trained or even employ ideological or fundamentalist arguments (Schleichert, 2004). This rational and objective attitude is also indispensable in the context of philosophy as transformative practice. When we philosophise, we also exchange rational arguments. So, where is the difference? In philosophy as scientific practice, we may learn the ability to rationally reconstruct philosophical questions and positions of tradition along with the ability to substantiate arguments logically and rationally from practically any philosopher or subject in a similar way. A text for a scientific journal must meet the same criteria, no matter whether it is written about Aristotle, Søren Kierkegaard, or Martin Heidegger. Now the difference becomes clear: Within philosophy as scientific practice, these philosophers so different from each other always emerge to have the same transformative potential. Philosophy as transformative practice alters the situation; it reveals a very different transformative potential. Simply put, this potential is the meaning each philosophy has for the life of the philosophising subject. This potential changes the philosophising subject in a very different manner. It gives the subject the opportunity to see and understand oneself, one's own life, the others, society, and the whole world in a completely new and unfamiliar way, through a new philosophical perspective. The point is to relate the new philosophical perspectives - often very diverse - to the most peculiar questions of life. Thus, philosophy as scientific practice also holds a valuable transformative potential. But this has little to do with the content of a particular philosophy. Although, it is this transformative potential that I seek in the context of education.

Now a second possible objection. Is philosophy for educational purposes absent also from universities? After all, Hadot (Hadot, 1995) and Foucault (Foucault, 1990) were academic teachers, too. In fact, transitions are fluid and the clear separation that I propose in this text is ultimately a simplification. We also should and must work on an scientific propaedeutic of philosophy in the context of education, something which actually happens. With good reason, examination regulations pursue an academic training in philosophy for teacher students at universities. While philosophy didactics is a science as well. On 
the other hand, even in an academic context, philosophers ask what is ethically correct and wrong, not only for the sake of professional philosophy but also when considering their role as citizens in society (Böhme, 1994: 26-30). Nevertheless, the distinction between philosophy as scientific practice and as transformative practice seems to me meaningful, because it can make us aware of how fundamentally different the practices of our philosophising are.

Once more, we have to keep in mind that academic philosophy is more than "competitive debating" and philosophy at school or at home is more than "self-help books".

\section{WHAT EXACTLY DOES THE TRANSFORMATION OF THE PHILOSOPHISING SUBJECT MEAN? THREE ATTEMPTS AT ANSWERS}

First, an example: the question of bioethics is presented during a philosophy class, e.g., from the field of germ-line therapy. Should we make changes in human germ cells, which are then passed on to future generations? This could prevent hereditary diseases or - perhaps - make the skin less susceptible to skin cancer. However, we could also create a slightly more beautiful skin type. Where is the dividing line between a justified therapy and the design of an optimal dream child? Pupils in class find many pros and cons when different positions on the problem are worked out and discussed. In their essay or exam, pupil A argues for solution $\mathrm{x}$ while pupil $\mathrm{B}$ for solution $\mathrm{y}$. Thus, the students also decide in which world they live and which values they want to defend. They decide in what way they want to be human (Böhme, 2001). Let us imagine that we are the teachers who have been teaching these students for many years. Hence, we would be pleased that the students defend diverse solutions. Because somehow the different argumentations fit our very different students. Why can we be happy about the individual ethical judgements and their justifications? Should we not be concerned with a single objective truth? We are happy because the aim of our work with pupils is not to lead them all to the same highest truth. We also rarely care about the state of research in the scientific community. The aim of philosophising in the context of education is for the students to understand various arguments of applied ethics and to develop and formulate their own position in a well-founded way. This happens through rational argumentation and discussion with arguments. However, in the context of our teaching, the rational serves a certain goal. The pupils should learn the ability to represent in a well-founded way their own position against the background of such elements as their own life, their perspective on their own life, and their own values. How can we better determine the meaning of transformation on the basis of this example? 


\subsection{To Raise the Transformative Potential of Different Philosophies}

I have argued above that every great philosophy gives birth to a theory of philosophy education. This is an implicit - unformulated - answer to the question of what must happen for someone to be considered philosophically educated (Dammer, 2015; Dammer \& Kirschner, 2017; Benner \& Brüggen, 2004). For Plato, philosophy education means the ability to understand and see through the essential reality of things and the world through some higher philosophical knowledge. For Immanuel Kant, one is philosophically educated after gaining a deep insight into the limits of a certain cognition (sichere Erkenntnis); and when one has gained an equally deep insight into the inner moral transcendence, the inner freedom to do what is necessary. Still, other ideas of true philosophy education emerge from other important philosophies. What is here the task of philosophy as transformative practice? And what is the task of teaching philosophy as part of the education of teacher students? The task is to make explicit the theories of philosophy education implied in the great philosophies; to give the philosophising subject a radically new view of themselves and the world, enabled by each great philosophy in its own way. It is important to relate this new view to the concrete situated subject, its life practices, and the life it has to lead. Hence, philosophising acquires a transformative meaning. ${ }^{2}$

\subsection{Major Themes of Transformation Through Philosophy}

There are great themes of transformation that originate in more than one philosophy. Allow me to offer a few examples below. We may say that the first theme shows philosophising as a means of becoming not only a good philosopher but a good person. Aristotle writes in Nicomachean etbics (Aristotle, 2014: $\mathrm{B} 2,1103 \mathrm{~b} 27-29)$ that, "we are inquiring not in order to know what virtue is, but in order to become good". Similarly, Kant wonders how people who actually know what to do can make themselves do it. Hence, Kant developed the idea of respect for the moral law (GMS, AA 04: 400.17-403.17 \& annot. 1; GMS, AA 04: 401.17-40; KU § 27 [AA 05: 257.06-260.07]). In turn, Lawrence Kohlberg was accused of merely training a formal moral ability with stages of moral judgment; namely, rational reasoning. Is it not more important to develop empathy in order to become a good person and form one's character

2 The concept of transformation in this text is different from Laurie Paul's concept of transformative experience, but there also are similarities. Coming from decision theory, Paul is interested in a lack of reasoning when we have to decide on actions that are both epistemically and personally transformative, like having a child or not. However, according to my approach, the emphasis is on transforming ourselves by philosophising - with a look on the classical German concept of Bildung (Paul, 2014). 
(Pritchard, 1984; Haidt, 2001)? We may understand transformation here as a deeper - not only cognitive - change towards good.

Another overriding theme of transformation is the path from other-determination to self-determination through philosophy. Aristotle's Nicomachean ethics positions becoming independent among the usual human goals like wealth or fame and the strengthening of reason in itself (Arist. Nic. eth. A 2-3 1095a14-1096a10, A 8-12 1098b9-1102a4). Epicurus's ethics seeks independence from our spontaneous feelings, be it fear or desire, and finally deciding for ourselves what is really important (Epicurus Ep. Men.). Kant's ethics aims to lead the philosophising subject from heteronomy to autonomy. Whereas Kierkegaard, Nietzsche, and Heidegger in various ways develop an ethics of authenticity and explicitly of one's own life. It is always a question of overcoming oneself as an externally determined subject to become both free and oneself.

I find the following overarching theme of transformation through philosophising particularly interesting. Some philosophies show a self-articulation that expands the philosophical discourse and terminology. If we read such authors as Foucault (Foucault, 1990), Butler (Butler, 2015), or Achill Mbembe (Mbembe, 2017), then we first notice suffering. These authors could not correctly articulate their worldview with the usual notions of discourse and normality. As members of minorities, they first had to realise that the discourse, notions, and normality they found were themselves restrictive and by no means neutral, as they related to the irreducible individual experiences of these philosophers. In a second step, the philosophers themselves had to develop new, better concepts. A prime example is the concept of heteronormativity as it is analysed vigorously by Butler (Butler, 2015: vii-xxviii, 1-46). Noteworthy, Butler does not use the term "heteronormativity" in Gender trouble which was in fact coined by Michael Warner in 1991 (Warner, 1991). These philosophers could only articulate themselves adequately in new concepts and completely new thoughts. In philosophy lessons at school, these authors and how they changed the discourse can serve as role models. Especially for those pupils who belong to minorities that are not represented in social elites, such as the children of migrants. The transformation here means to recognise the restriction of normality and subsequently expand the existing philosophical discourse, thus articulating oneself.

A fourth overarching theme of transformation through philosophising concerns the radical change that occurs when we gain a deep and clear insight into the principal limits of our knowledge through philosophising. Socrates (Pl. Ap.; Pl. Tht.) and Kant (Critique of pure reason - AA 01) represent this tradition. Even more radical is the twentieth-century reflection on negativity. Late Ludwig Wittgenstein persuasively argued that we can only comprehend the constitution of sense within our worlds of meaning, but that we ourselves 
cannot justify these worlds of meaning from the outside: "You must bear in mind that the language-game is so to say something unpredictable. I mean: it is not based on grounds. It is not reasonable (or unreasonable). [...] It is there - like our life" (Wittgenstein, 1969: 73e, No. 559).

"The difficulty is to realize the groundlessness of our believing" (Wittgenstein, 1969: 24e, No. 166). Based on these insights into the impossibility of reasoning, philosophers like Stanley Cavell describe the transformative process. In this process, we alienate ourselves from the world in the sense of a fundamental scepticism: the world disintegrates because nothing can be properly reasoned. In the next step, we can regain the world in a completely new way. Cavell speaks of a "willingness for the everyday" (Cavell, 1988: 178). Such transformation means losing the world through philosophising and regaining it in a different manner.

\subsection{The Examination of Educational Theories}

We can probably only really understand what transformation means according to philosophy as transformative practice when we deal with the philosophy of education and with general theories of education (cf. Siljander, Kivelä, \& Sutinen, 2012). Where do similarities and differences exist between the transformation through philosophising and those according to different educational theories? We may relate to transformative philosophy the concepts of education by Wilhelm von Humboldt (cf. Konrad, 2012), Johann Friedrich Herbart (cf. Siljander, 2012), John Dewey (cf. Juuso, 2012), or Otto Friedrich Bollnow (Bollnow, 2014). I deem as particularly fruitful a comparison of the above with the approach of Hans-Christoph Koller, who regards himself as a proponent of a transformative educational theory (Koller, 2012).

On the other hand, what is the special element, the property (das Proprium) of philosophy education? Although the great theories of education are concerned with education as a whole, here we are dealing with a specific philosophy education. What can we learn only through philosophy and not from any other discipline? Are there completely individual paths and goals of philosophy education, understood as the transformation of the situated subject? These are important research questions. We are unable to give an answer here. However, we may assume that this answer will concentrate on the concept of reason, so central to philosophy (cf. Rapp et al., 2001). This is a matter of forming a strong reason and one that is multifaceted. Reason is a discourse of rational reasoning that never ceases. At the same time, it is typical of philosophy that reason as the final authority of a never-finished critique prevails over all belief and intent (das Meinen). Thus, a cycle of reasoning and critique emerges. Simultaneously, reason is critical of itself, for instance of its own 
rationalistic constriction. This means, for instance, that reason resists its appropriation by extra-rational purposes: instrumental reason is important, but it is not the ultimate goal (Habermas, 1987). After all, reason always remains open to wisdom. This is also the unique aspect of reason: that it can deal with unsolvable questions and formulate them without falling into ideology. Reason can uncover and keep open new dimensions of things and the world, precisely by constantly exceeding all models, constructs, big pictures, and every usual understanding. Here, the transformative of philosophising has the meaning of an ongoing transgressing/transcending. We must seek the special element of philosophy education precisely in this intrepid, courageous transgression. Therefore, as philosophy overwhelms us, it often seems too difficult. What actually overtaxes us is the enormous strength of reason, its ability to critically exceed the whole of our accustomed world. Great philosophies have repeatedly opened doors to completely new spaces. However, these new spaces appear to have everything completely different, which makes orientation seem impossible at first. Our reason is also this transforming-transcending movement, which always breaks new ground. In summary: What does transformation within the framework of philosophy education actually mean? It is not about firm answers to big questions; it is not about models of understanding and orientation; although many people expect this from philosophy and from philosophy lessons at schools. Philosophy education is more about saying goodbye to the understanding of ourselves and the world, to which we have become accustomed and with which we are familiar. Philosophy education is about the courageous step into completely open ground, in which we can no longer orient ourselves and understand the world. Here we experience anxiety, danger, and incomprehension. These are not the goal but the necessary price for philosophy education.

Philosophy as transformative practice is a concept of philosophy that is more appropriate to the educational context than philosophy as scientific practice. The most important reason for this is that, here, the philosophical processes of cognition are always connected with a transformation of the philosophising subject. Hence, I propose that we teach philosophy in teacher training courses not only as scientific but also as a transformative practice.

\title{
BIBLIOGRAPHY
}

\author{
Abbreviations \\ AA — Kant, I., Akademieausgabe (Kants Gesammelte Scbriften) \\ GMS - Kant, I., Grundlegung der Metaphysik der Sitten \\ KU - Kant, I., Kritik der Urteilskraft \\ Arist. Nic. eth. - Aristotle, Nicomachean etbics \\ Epicurus Ep. Men. - Epicurus, Epistula ad Menoeceus (Letter to Menoeceus)
}


Nov. Org. - Bacon, F., Novum Organum

Pl. Ap. - Plato, Apology of Socrates

Pl. Tht. - Plato, Theatetus

Aristotle. (2014). Nicomachean ethics. (C.D.C. Reeve, Trans.). Indianapolis et al.: Hackett.

Benner, D. \& Brüggen, F. (2004). Bildung / Bildsamkeit (pp. 174-215). In: D. Benner \& J. Oelkers (Eds.). Historisches Wörterbuch der Pädagogik. Weinheim-Basel: Beltz Verlag.

Böhme, G. (1994). Wissenschaft, Weltweisheit, Lebensform. Eine Einfübrung in die Philosophie. Frankfurt a. M.: Suhrkamp.

Böhme, G. (2001). Ethics in context. The art of dealing with serious questions. (E. Jephcott, Trans.). Cambridge-Malden: Polity Press.

Bollnow, F.O. (2014). Existenzphilosophie und Pädagogik. Krise und neuer Anfang (= Studienausg., 8). Würzburg: Königshausen \& Neumann.

Butler, J. (2015). Gender trouble. Feminism and the subversion of identity. New York-London: Routledge, Taylor \& Francis Group.

Cavell, S. (1988). In quest of the ordinary. Lines of scepticism and romanticism. Chicago: University Press.

Dammer, K.-H. (2015). Philosophen als Pädagogen (vol. 1). Opladen et al.: Budrich.

Dammer, K.-H. \& Kirschner, A. (2017). Philosophen als Pädagogen (vol. 2). Opladen et al.: Budrich.

Feinberg, J. (2002). Doing philosophy. A guide to the writing of philosophy papers. (2 ${ }^{\text {nd }}$ ed.). Belmont et al: : Wadsworth, Thomson Learning.

Foucault, M. (1982). The subject and power. Afterword (pp. 208-225). In: H. Dreyfus \& P. Rabinow (Eds.). (2003). Michel Foucault. Beyond structuralism and hermeneutics. ( $2^{\text {nd }}$ ed.). Chicago: University of Chicago Press.

Foucault, M. (1990). The history of sexuality (vol. 3). (R. Hurley, Trans.) London: Penguin Books.

Habermas, J. (1987). Knowledge and buman interests. (J.J. Shapiro, Trans.), Cambridge et al.: Polity Press.

Hadot, P. (1995). Philosophy as a way of life. Spiritual exercises from Socrates to Foucault. (M. Chase, Trans.). Oxford-Cambridge: Basil Blackwell.

Hadot, P. (2002). What is ancient philosophy?. (M. Chase, Trans.). London-Cambridge: Harvard University Press.

Haidt, J. (2001). The emotional dog and its rational tail: A social intuitionist approach to moral judgment. Psychological Review, 108(4), 814-834.

Heidegger, M. (1927/1996). Being and time. (J. Stambaugh, Trans.). Albany: State University of New York Press.

Juuso, H. (2012). The origins and educational significance of John Dewey's philosophy (pp. 227-246). In: P. Siljander, A. Kivelä, \& A. Sutinen (Eds.). Theories of Bildung and growth. Connections and controversies between continental educational thinking and American pragmatism. Rotterdam: Sense Publishers.

Kant. I. (1900ff.). Kants Gesammelte Scbriften. (Akademieausgabe). Königlich Preußische Akademie der Wissenschaften. Berlin: Reimer / de Gruyter.

Koller, H.-Ch. (2012). Bildung anders denken. Einfübrung in die Theorie transformatorischer Bildungsprozesse. Stuttgart: Kohlhammer.

Konrad, F.-M. (2012). Wilhelm von Humboldt's contribution to a theory of Bildung (pp. 107124). In: P. Siljander, A. Kivelä, \& A. Sutinen (Eds.). Theories of Bildung and growth. Connections and controversies between continental educational thinking and American pragmatism. Rotterdam: Sense Publishers. 
Mannheim, K. (1929/1936). Ideology and utopia. An introduction to the sociology of knowledge. (L. Wirth \& E. Shils, Trans.). London: Routledge and Kegan Paul.

Mbembe, A. (2017). Critique of black reason. (L. Dubois, Trans.). Durham-London: Duke University Press.

Nida-Rümelin, J., Spiegel, I., \& Tiedemann, M. (Eds.). (2017). Handbucb Pbilosophie und Ethik (vols. 1-2). (2 $2^{\text {nd }}$ ed.). Paderborn: Ferdinand Schöningh.

Paul, L. (2014). Transformative experience. Oxford: Oxford University Press.

Peters, M. \& Peters, J. (2019). Moderne Philosopbiedidaktik. Basistexte. Hamburg: Meiner.

Pritchard, M.S. (1984). Cognition and affect in moral development: A critique of Lawrence Kohlberg. The Journal of Value Inquiry, 18(1), 35-49.

Rapp, Chr. et al. (2001). Vernunft / Verstand (vol. 11, col. 748-863). In: J. Ritter, K. Gründer, \& G. Gabriel (Eds.). Historisches Wörterbuch der Philosopbie. Darmstadt: Wissenschaftliche Buchgesellschaft.

Schatzki, Th.R. (2001). Introduction: Practice theory (pp. 10-23). In: Th.R. Schatzki, K. Knorr-Cetina, \& E. von Savigny (Eds.). The practice turn in contemporary theory. London: Routledge.

Schleichert, H. (2004). Wie man mit Fundamentalisten diskutiert, obne den Verstand zu verlieren oder Anleitung zum subversiven Denken. (4 $4^{\text {th }}$ ed). München: Beck.

Shusterman, R. (2013). Philosophy as a way of life. As textual and more than textual practice (pp. 40-56). In: M. Chase, S. Clark, \& M. McGhee (Eds.). Philosopby as a way of life. Ancients and moderns. Essays in honor of Pierre Hadot. Chichester-Malden: Wiley-Blackwell.

Siljander, P. (2012). Educability and Bildung in Herbart's theory of education (pp. 87-106). In: P. Siljander, A. Kivelä, \& A. Sutinen (Eds.). Theories of Bildung and growth. Connections and controversies between continental educational thinking and American pragmatism. Rotterdam: Sense Publishers.

P. Siljander, A. Kivelä, \& A. Sutinen (Eds.). Theories of Bildung and growth. Connections and controversies between continental educational thinking and American pragmatism. Rotterdam: Sense Publishers.

Stelzer, H. (2017). Lebensweltbezug (pp. 79-86). In: J. Nida-Rümelin, I. Spiegel, \& M. Tiedemann (Eds.). Handbuch Pbilosophie und Ethik (vol. 1). (2 $2^{\text {nd }}$ ed.). Paderborn: Ferdinand Schöningh.

Stern, D.G. (2003). The practical turn (pp. 185-206). In: S.P. Turner \& P.A. Roth (Eds.). The Blackwell guide to the philosophy of the social sciences. Malden-Oxford: Blackwell Publishing.

Thomas, Ph. (2019). Philosophie als transformative Praxis (PTP). Vom bildenden Potenzial der Philosophie. Publikationssystem der Universitätsbibliothek Tübingen. Retrieved from: http://hdl.handle.net/10900/87339 (14.08.2019).

Tiedemann, M. (2017). Problemorientierung (pp. 70-78). In: J. Nida-Rümelin, I. Spiegel, \& M. Tiedemann (Eds.). Handbuch Philosophie und Ethik (vol. 1). (2 ${ }^{\text {nd }}$ ed.). Paderborn: Ferdinand Schöningh.

Warner, M. (1991). Introduction: Fear of a queer planet. Social Text, 29, 3-17.

Wittgenstein, L. (1922/1949). Tractatus logico-philosophicus. (C.K. Odgen, Trans.). (4 ${ }^{\text {th }}$ ed.). London: Routledge \& Kegan Paul.

Wittgenstein, L. (1953). Philosophische Untersuchungen/ Philosophical Investigations. (G. E. M. Anscombe, Trans.). Oxford: Blackwell.

Wittgenstein, L. (1969). Über Gewissheit / On Certainty. (D. Paul \& G.E.M. Anscombe, Trans). Oxford: Basil Blackwell. 
